\title{
sustainability
}

ISSN 2071-1050

www.mdpi.com/journal/sustainability

Article

\section{Change of Land Use Patterns in the Areas Close to the Airport Development Area and Some Implicating Factors}

\section{Kanokporn Swangjang ${ }^{1, *}$ and Visut Iamaram ${ }^{2}$}

1 Department of Environmental Science, Faculty of Science, Silpakorn University, Nakorn Pathom 73000, Thailand

2 Banpu Public Company Limited, 1550 New Petchaburi Road, Makkasan, Ratchathewi, Bangkok 10400, Thailand; E-Mail: visut.iamaram@gmail.com

* Author to whom correspondence should be addressed; E-Mail: knokporn@su.ac.th; Tel.: +66-34-219146; Fax: +66-34-273047.

Received: 15 April 2011; in revised form: 25 June 2011 / Accepted: 7 September 2011 / Published: 20 September 2011

\begin{abstract}
This paper presents the description of land use change in the suburbs near Suvarnabhumi International Airport, with a focus on land use patterns before and during airport development. According to geographic information system (GIS), land use patterns are categorized into three main groups, namely intensive urban development land, areas developed under environmental conditions, and natural land. Steps of land use changes, land use planning and related factors concerning number of population, dwelling units and factories were analyzed. In the short term, urban development dramatically increases by $39.97 \%$ whereas the areas developed under environmental conditions decreased by $37.52 \%$, with significant correlation $(P<0.05)$. The natural land which is typically grassland and watercourses changed insignificantly $(P>0.05)$. Urbanization of the areas where the airport is located increased between $10.07 \%$ and $15.57 \%$. The changes of land use comply with the Integrated Town and Country Planning. The areas where urbanization is small are under the area designated as the green area. Urban expansion is mainly a result of increase in residential areas which is closely related to number of population. Such changes indicate a need for more effective urban development planning and management to conserve environmental quality.
\end{abstract}

Keywords: land use change; town and country planning; Suvarnabhumi Airport 


\section{Introduction}

Change of land use patterns to urban areas has become a major problem resulting from economic and population growth, especially in developing countries [1-5]. The urbanization process which has resulted from both direct and indirect influences is multi-directional and differentiated in time and space [6]. People transform natural habitats into man-made landscapes of residential, commercial, institutional and industrial areas as well as supporting infrastructure [7]. Fast-growing populations need a large number of living units, as pointed out by [8]. Poor land use planning is another factor contributing to uncontrolled expansion of the urban area [9]. As a consequence of urbanization, most natural lands have been fragmented into small pieces of lands likely to create adverse environmental impacts [4,5]. According to Martinuzzi et al. [10], unlimited urbanized areas or "urban sprawl" affects resource consumption and causes environmental impacts.

The importance of landscape change, both temporally and spatially, has been addressed in a number of studies [5,6,11-16]. It is essential to understand causes and effects of such changes on the environment in both developed and developing countries, at both micro and macro levels; for example, a decrease in agricultural and ecological lands in China [9,17], the similar study conducted in the United States $[4,16]$, the rapid growth in the peri-urban zones in developing countries resulted from increased commercial development [18], the growth of urban area in relation to population growth in China [19], and prediction of the effects of land use change on water supply in the watershed area by the model [20]. Such studies illustrate the causes and effects as well as recommendations on integrating the findings into plans and policies under a sustainability goal, as confirmed by the study of Musacchino and Coulson [21] and Brunckhorst et al. [22].

A number of studies related to land use planning lands have been carried out, using Geographic Information Systems (GIS). Although GIS can be applied to spatial aspects, an analytical mechanism depends on the purpose of application and spatial settings, for examples, Oh et al. [23], Bailey et al. [24] and Pauliet et al. [11], in which various categories of land use patterns have been identified and different conclusions were made.

In this study, the hypothesis is set that the change of land use pattern has been initiated by development of mega projects as the main driving force for urbanization rate. Contribution ratio of urban growth which may affect the areas of ecological interest as a result of the change of natural landscape is also pinpointed. Characteristics of the change of other land use patterns to "urban sprawl" are important in terms of environmental sustainability. During the last fifteen years, development of land around the Suvarnabhumi International Airport has dramatically increased. Not only transportation networks and infrastructures to support the airport, but also rapid property development projects in various forms to serve the demand of new communities are one of the challenges which transform green areas into urban lands.

Suvarnabhumi International Airport, the latest of ASEAN's international airport, is of prime concern for the following reasons: there are a great number of development projects within the area; the area was originally a green belt; and local people's way of life, i.e., mainly farmers. The airport is located on a total area of 32,000 square kilometers in Rachathewa and Nong Prue sub-districts, in Samut Prakarn province, east of Bangkok Metropolis. In 1996, the development of the airport started 
with the relocation of local people from the airport site and then construction began. The airport was commenced in September 2006.

According to Thailand's hierarchical administrative system, the local administration is divided, from the smallest to the highest units, into tambon or sub-district, amphoe or district and province. It is important to scope down the study area according to those official local administration areas since all available data to be used in this study, including land use GIS themes and target population, are grouped in accordance with the local administration. Two districts, namely Bang Pli and Bang Sao Thong, of Samut Prakarn province, are selected. These two districts govern nine sub-districts, namely Bang Pli Yai, Bang Kaew, Bang Pla, Rachathewa, Nong Prue, Bang Cha Hlong in Bang Pli district and Bang Sao Thong, Srisajorakhe Noi, Srisajorakhe Yai in Bang Sao Thong district. Originally, the two districts were under one single administrative area, so-called Bangpli district. Then in 1995, they were separated into two districts. However, the airport is located in Bangpli district (see Figure 1).

Figure 1. Study area.

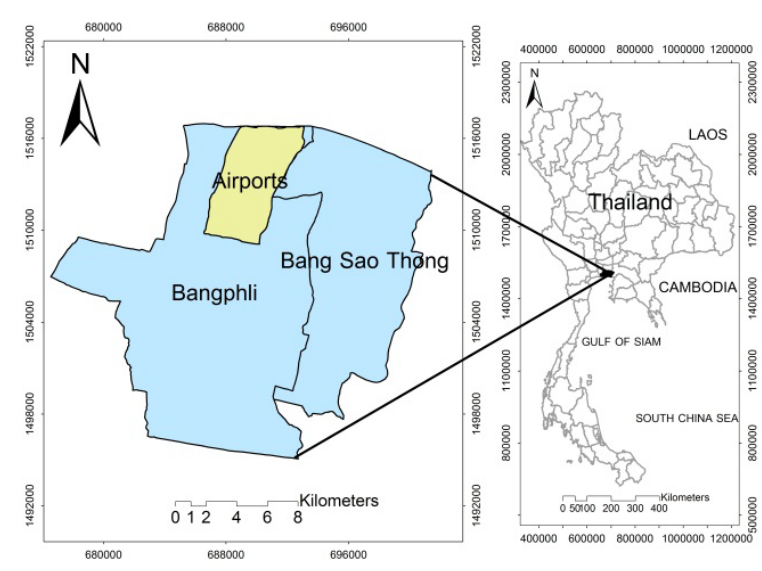

This paper presents an evaluation of the change of land use as a result of the mega project development. Causes and efficiency of the Integrated Town and Country Planning which is a tool to control urban expansion are examined for the relationship to land use change. Land use patterns are considered from both spatial and temporal aspects. The characteristics of the changes will support the measures to conserve the environmental capability according of each land use potential.

\section{Methods}

\subsection{Land Use Analysis}

In this research, data preparation, input, subsequent map operations, and spatial data analyses were carried out using ArcGIS 9.3. GIS layers of Bang Pli and Bang Sao Thong districts, from Department of Environmental Quality Promotion (DEQP) of Thailand, are applied for mapping land use patterns in 1994 and 2002 which were the years before and during airport development, respectively. This study attempts to employ the earliest stage of airport development in order to illustrate the initial phase of land use transformation. In Thailand, land use patterns have been changed before mega project construction took place. Therefore, GIS layers after 1996 were selected as representative of the land use patterns in such duration. 
For GIS layers, land use types/categories in one year are different from another. In the analysis, land use categories are grouped into three main types according to physical appearance and environmental feature, adapted from Hara, Takeuchi and Okubo [25]. The land is divided as shown in Table 1 . The area of each land use category is calculated by sub-district.

Comparison on land use development based on the interpretation of GIS themes in each sub-district in 1994 and 2002 and statistical correlation (paired T-Test) using the Statistical Package for the Social Science for Window (SPSS) Version 18.0 is analyzed for changes in both spatial and temporal aspects.

Table 1. Criteria of potential land use patterns.

\begin{tabular}{ccl}
\hline Group & Criteria & Land use categories according to GIS layers \\
\hline \multirow{3}{*}{$* *^{1}$} & Intensive urban & - town and commercial \\
& - industry and industrial estate \\
& & - institution \\
& & - urban and built up land, village \\
& - airport \\
& & - paddy field and upland rice \\
$\mathrm{B} *^{2}$ & Area developed under & - agricultural area; kenaf, jute, orchards, mixed fruits \\
& environmental & - farmhouses; pasture and farmhouse, poultry farmhouses \\
& conditions & - fish farms and aquaculture \\
& & - recreation area and golf courses \\
& & - soil pit \\
\hline \multirow{2}{*}{$\mathrm{C}$} & Natural environment & - natural water bodies, upland bog \\
& - rangeland
\end{tabular}

*1 Intensive development-Land use pattern has completely been changed to urban area and cannot be reversed to the former green area; ${ }^{* 2}$ Area developed under designated environmental conditions-The areas are still the green area and can be changed to other land use patterns in the same environmental condition, such as from paddy field to fish farm.

\subsection{Integrated Town and Country Planning}

The Integrated Town and Country Planning maps and 1:50,000 military maps are overlaid and the sub-district boundaries are adjusted to fit the proper scales. With ArcGIS 9.3 spatial operation, percentage of each land use group in each sub-district is calculated.

\subsection{Related Factors}

There are three main factors related to urban growth including number of population, number of dwelling units and number of factories. Population growth is a main factor for urban sprawl and closely related to number of dwelling units. For industrial aspect, there are three major industrial estates and a number of factories in the study area. These factors are considered for their relationship with land use change in the period of the mega project development.

Statistical data of population, dwelling units and factories during 1993-2005 obtained from Department of Provincial Administration of Thailand are analyzed. The results are compared with the result of land use change from ArcGIS analysis. 


\section{Results and Discussion}

\subsection{Land Use Change}

Land use patterns of the study area in 1994 and 2002 are shown in Figure 2 and Figure 3, respectively and the percentage differences of the whole area are shown in Table 2. The rearranged color legends are shown in Figure 4 and Figure 5. In GIS layers, the SI unit (square meter) is used for the area expression and percentage of each land use pattern to the whole area is used in comparison, for easy understanding.

Table 3 presents the percentage change of land use in Group A, B and C between 2002 and 1994 of each sub-district.

Change of land use to intensive urban development (Group A) dramatically increased by $39.97 \%$. There is statistical correlation of such changes $(P<0.05)$, as indicated by paired $T$-Test (Table 4$)$. When considering the land use area by district as presented in Table 3, it is found that Bang Kaew shows the highest urbanization (33\%). Considering its location, it is found that this area is close to Bangkok Metropolis and accessible to transportation network. The development is not caused solely by the airport development.

Figure 2. Land use in 1994.

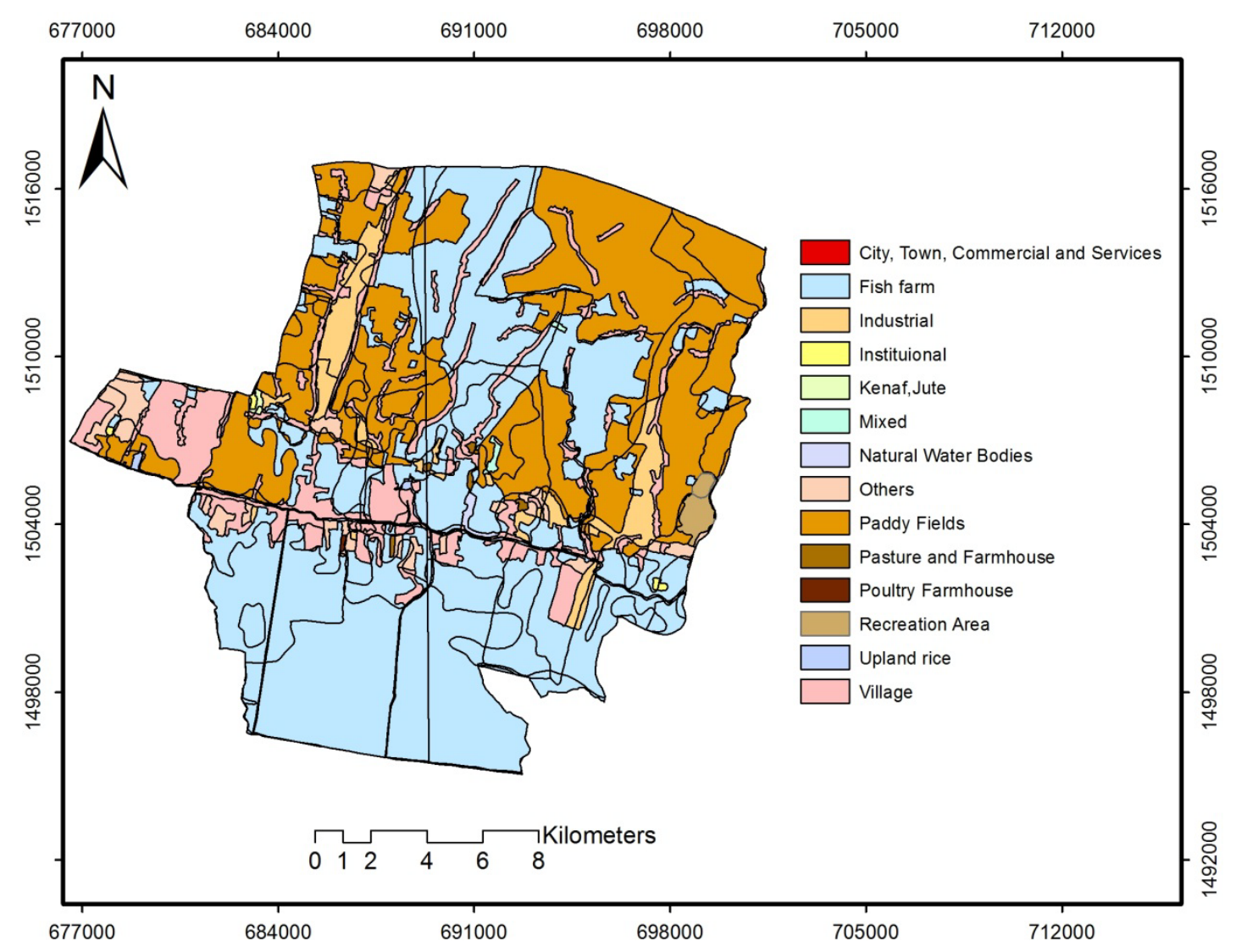


Figure 3. Land use in 2002.

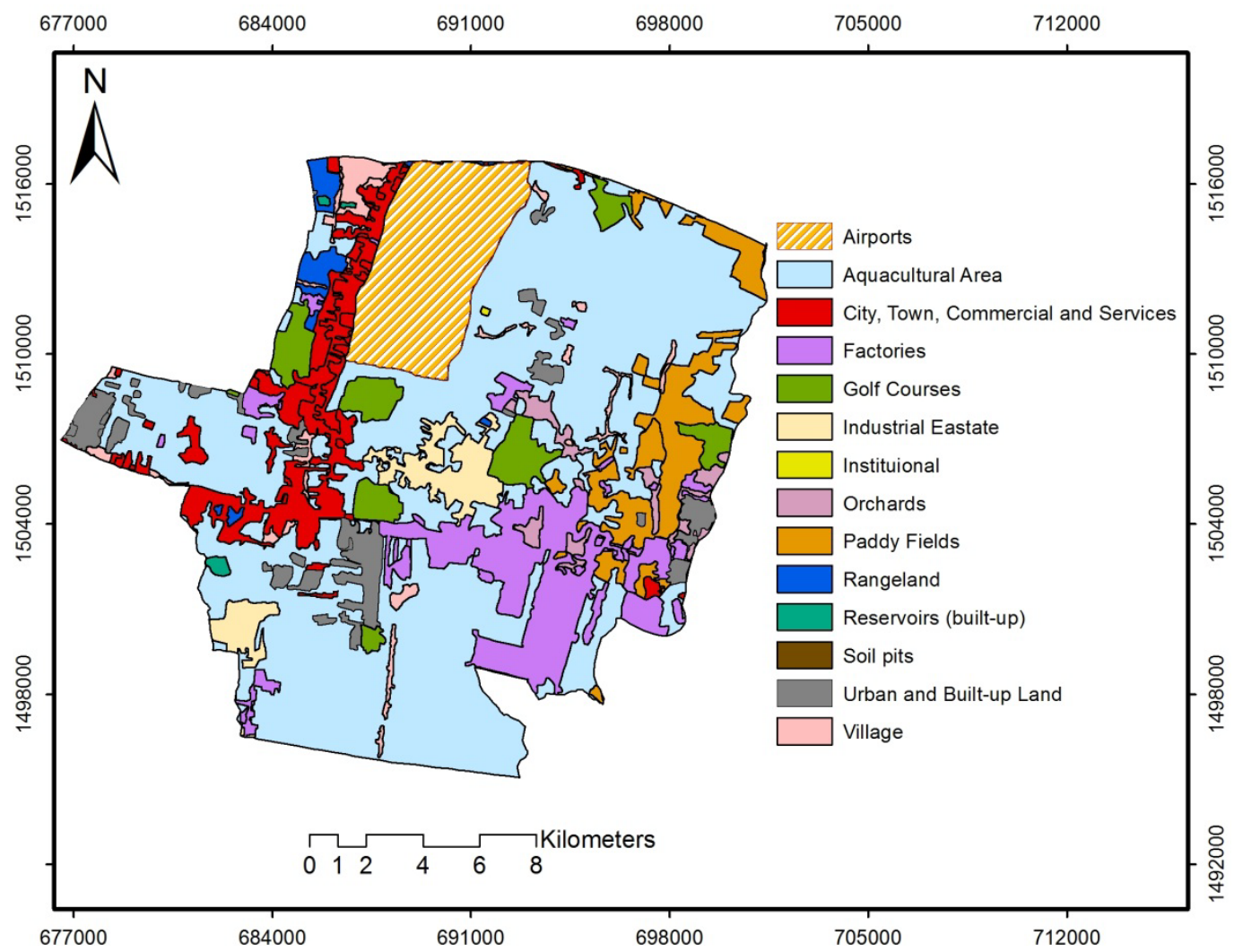

Figure 4. Rearranged color legends by groups of 1994 land use.

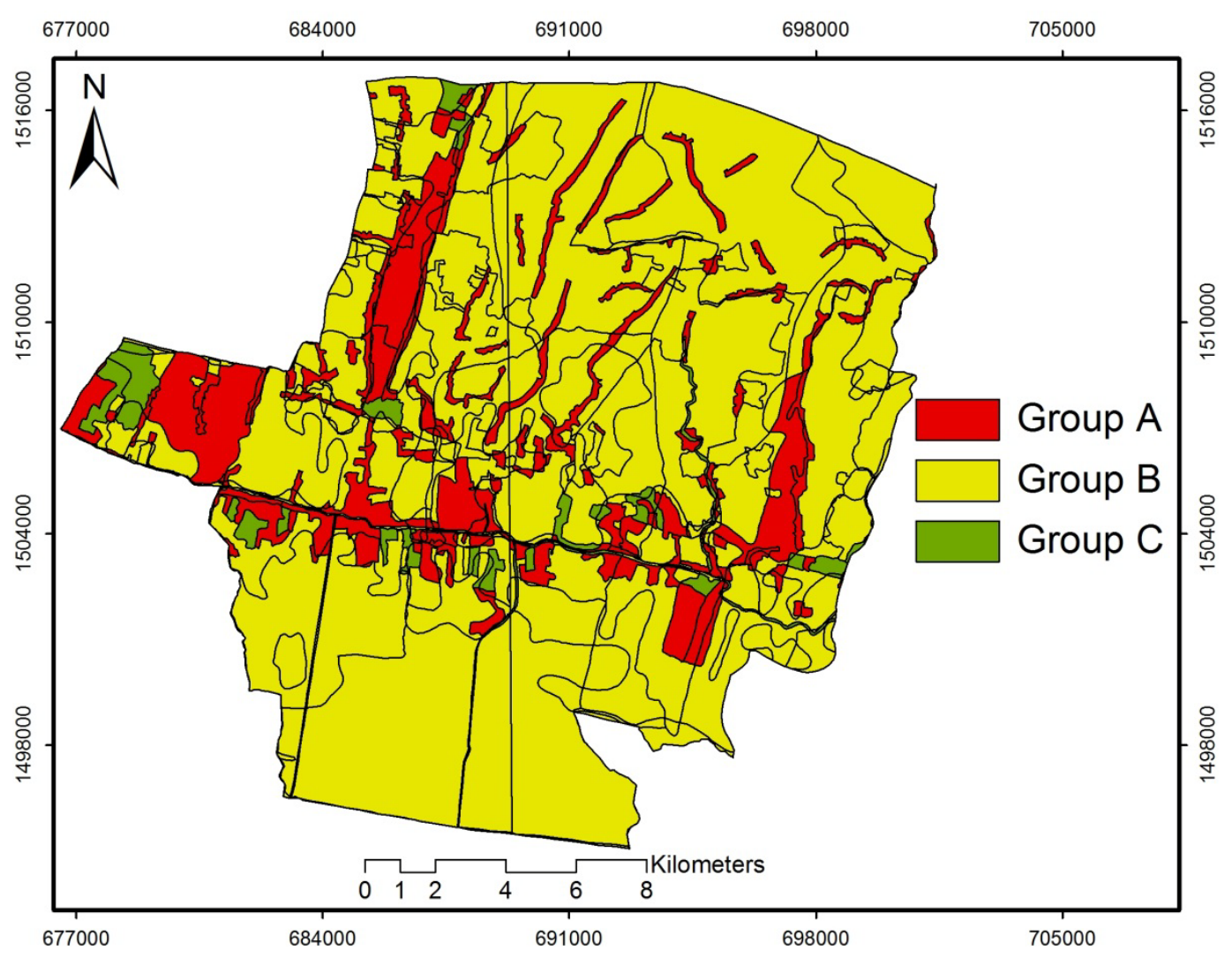


Figure 5. Rearranged color legends by groups of 2002 land use.

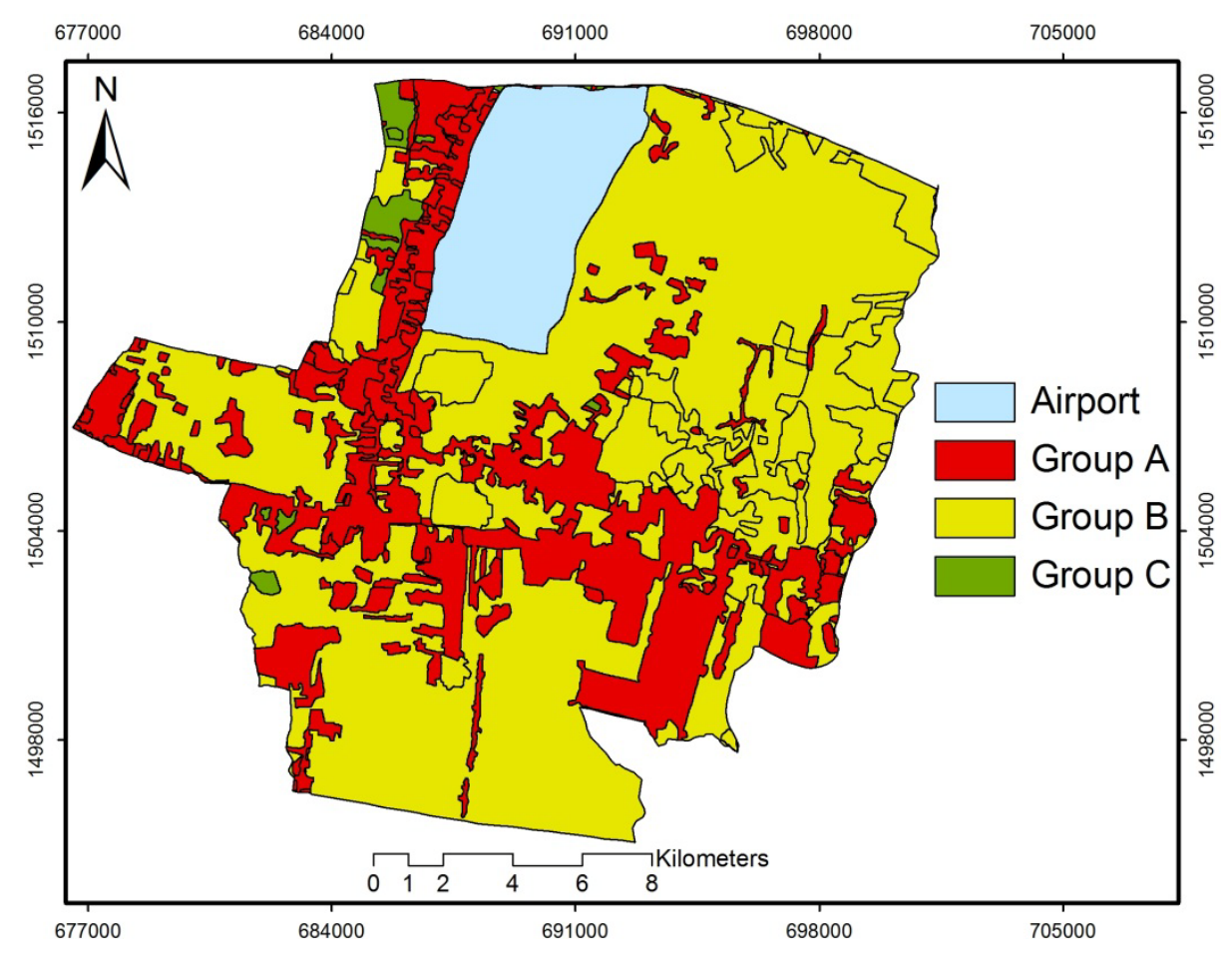

Table 2. Land use change by groups during 1994 to 2002.

\begin{tabular}{lccc}
\hline Land use & $\mathbf{1 9 9 4}$ & $\mathbf{2 0 0 2}$ & Percentage changed \\
\hline .1 Intensive urban development & & & \\
- town and commercial & 0.0006 & 5.3092 & 5.3086 \\
- industry and industrial estate & 2.6742 & 40.4745 & 37.8003 \\
- institution & 0.0725 & 0.0048 & -0.0677 \\
- urban and built up land, village & 8.6459 & 1.5478 & -7.0981 \\
-airport & Nil & 4.0280 & 4.0280 \\
Total & $\mathbf{1 1 . 3 9 3 2}$ & $\mathbf{5 1 . 3 6 4 3}$ & $\mathbf{3 9 . 9 7 1 1}$ \\
\hline .2Area developed under environmental & & & \\
conditions & & & \\
- paddy field and upland rice & 27.2802 & 1.3879 & -25.8924 \\
- agricultural area; kenaf, juite, & 0.1267 & 0.7669 & 0.6403 \\
orchards, mixed fruits & & & \\
-farmhouses; pasture and farmhouse, & 0.1262 & nil & -0.1262 \\
poultry farmhouses & & & -12.7215 \\
- fish farms and aquaculture & 57.6773 & 44.9559 & 0.5762 \\
-recreation area and golf courses & 0.6473 & 1.2234 & 0.0011 \\
- soil pit & Nil & 0.0011 & $-\mathbf{3 7 . 5 2 2 6}$ \\
Total & $\mathbf{8 5 . 8 5 7 7}$ & $\mathbf{4 8 . 3 3 5 2}$ & -0.3083 \\
\hline .3Natural environment & & & 0.2568 \\
-natural water bodies, upland bog & 0.3519 & 0.0436 & $-\mathbf{0 . 0 5 1 4}$ \\
-rangeland & Nil & 0.2568 & $\mathbf{0 . 3 0 0 5}$ \\
Total & $\mathbf{0 . 3 5 1 9}$ & & \\
\hline
\end{tabular}

Note: increase (+), decrease (-). 
Table 3. Land use change separated by sub districts during 1994 to 2002.

\begin{tabular}{lccc}
\hline \multirow{2}{*}{ Sub districts } & \multicolumn{3}{c}{ Land use change between 1994 and 2002 (unit: percentage) } \\
\cline { 2 - 4 } & Group A & Group B & Group C \\
\hline Bang Pli Yai & -4.4204 & 5.6803 & 0.6701 \\
Bang Kaew & 33.1540 & -17.1085 & Nil \\
Bang Pla & 12.2072 & -10.9954 & -0.2577 \\
Bang Chahlong & 14.6450 & -12.6714 & -1.0180 \\
Rachathewa* & 10.0707 & -9.4104 & 1.7387 \\
Nong Prue* & 15.5670 & -15.6061 & 0.0391 \\
Bang Sao Thong & 1.0795 & 1.9362 & -0.6836 \\
Srisajorakhe Noi & -1.4836 & 1.4836 & 1.4836 \\
Srisajorakhe Yai & 3.8904 & -2.3554 & -0.8316 \\
\hline
\end{tabular}

Note: * the areas where Suvarnabhumi Airport located.

Table 4. Statistic correlation of land use change by groups.

\begin{tabular}{|c|c|c|c|c|c|c|c|c|}
\hline \multirow{3}{*}{$\begin{array}{c}\text { Land use } \\
\text { comparison } \\
\text { Between } \\
1994 \text { and } \\
2002\end{array}$} & \multicolumn{5}{|c|}{ Paired Differences } & \multirow{3}{*}{$T$} & \multirow{3}{*}{ Df } & \multirow{3}{*}{ Sig. (2-tailed) } \\
\hline & \multirow[t]{2}{*}{ Mean } & \multirow[t]{2}{*}{$\begin{array}{c}\text { Std. } \\
\text { Deviation }\end{array}$} & \multirow{2}{*}{$\begin{array}{l}\text { Std. } \\
\text { Error } \\
\text { Mean }\end{array}$} & \multicolumn{2}{|c|}{$\begin{array}{l}\text { 95\% Confidence } \\
\text { Interval of the } \\
\text { Difference }\end{array}$} & & & \\
\hline & & & & Lower & Upper & & & \\
\hline Group A & -9.4133 & 11.43999 & 3.81333 & -18.2069 & -0.6198 & -2.469 & 8 & $0.039 *$ \\
\hline Group B & 6.5622 & 8.38407 & 2.79469 & 0.1177 & 13.0068 & 2.348 & 8 & $0.047 *$ \\
\hline Group C & 0.0378 & 0.84591 & 0.28197 & -0.6124 & 0.6880 & 0.134 & 8 & 0.897 \\
\hline
\end{tabular}

Note: * significantly different at $\alpha 0.05$

Urbanization in Rachathewa and Nong Prue where the airport is located is $10.07 \%$ and $15.57 \%$, respectively. Such development is less than half of that in Bang Kaew. The airport covers around 10\% of the total area of the two sub-districts. For Group A, urbanization is mainly caused by the expansion of housing and related property projects, whereas the number of factories does not significantly change.

For areas developed under environmental conditions (Group B), land use change decreased almost $37.52 \%$, with statistical correlation $(P<0.05)$. The reduction in percentage of this group is close to the increasing percentage of Group A. From site investigation, the pattern of change is from agricultural lands to golf courses, or change of crop types. The environmental conditions, such as topography, soil characteristics and drainage pattern, are key factors for such development. Such factors are limited in Group A which is a city. It can be seen from Table 3 that the areas of this group decreased in six out of nine sub-districts under consideration, especially in Bang Kaew.

Natural lands (Group C), natural watercourses and grassland, slightly decreased over time and no statistical significance was found. However, natural lands in Rachathewa and Nong Prue increased and in other sub-districts decreased. Unsurprisingly, those are the areas where the airport is located. The huge area south to the airport was reserved for the buffer zone of the runway. This area is situated in the two districts as mentioned before and comprises water courses which have been enlarged from the original size and grassland. Although, the percentage of land use change in Group C is negligible, the 
land area is significant in environmental conservation. Transformation of this land use group depends on topographic characteristics of the area which does not support any development.

\subsection{Urban Planning}

In Thailand, the Integrated Town and Country Planning Act was adopted in 1975, to be enforced by the Department of Public Works and Town and Country Planning. However, up to the present time, only $10,000 \mathrm{~km}^{2}$ or $2.7 \%$ from the total country area of $513,115 \mathrm{~km}^{2}$, has been announced as land use planning areas. Lack of land use planning is also a major problem to control urban expansion. Within the study area, it was in 1994 when the draft Integrated Town and Country Planning was initiated and then it has been amended from time to time. Finally, the Integrated Town and Country Planning was issued in 2001, covering the whole Samut Prakarn province. The study areas are located in two of the six districts of Samut Prakarn province. Five land use types, namely green and agricultural area, light density residential area, medium density residential area, high density residential area, and industrial area have been established. Environmental-affecting projects developed after 2001, when the Integrated Town and Country Planning was in effect, was considered. When considering the timing of the airport development, it seems that the Integrated Town and Country Planning was slightly late, only one year before commencement of the airport construction.

Land use lands under the Integrated Town and Country planning (2001) in each sub-district was analyzed by overlay mapping technique, as illustrated in Table 5. It was found that there are some differences of land use planning in Bang Pli and Bang Sao Thong. Urban growth in Bang Pli is more flexible than in Bang Sao Thong.

Table 5. Land use types as specified in the Integrated Town and Country Planning (2001). (unit: percentage).

\begin{tabular}{|c|c|c|c|c|c|}
\hline Land use types & \multirow{2}{*}{$\begin{array}{c}\text { Green and } \\
\text { agricultural } \\
\text { area }\end{array}$} & \multirow{2}{*}{$\begin{array}{c}\text { Low density } \\
\text { residential } \\
\text { area }\end{array}$} & \multirow{2}{*}{$\begin{array}{c}\text { Medium } \\
\text { density } \\
\text { residential area }\end{array}$} & \multirow{2}{*}{$\begin{array}{l}\text { High density } \\
\text { residential } \\
\text { area } \\
\end{array}$} & \multirow{2}{*}{$\begin{array}{c}\text { Industrial } \\
\text { area }\end{array}$} \\
\hline Areas & & & & & \\
\hline \multicolumn{6}{|l|}{ Bang Pli } \\
\hline Bang Pli Yai & 25 & 15 & 50 & 10 & \\
\hline Bang Kaew & & & 90 & & 10 \\
\hline Bang Pla & 80 & 15 & & & 5 \\
\hline Rachathewa* & 5 & & & 70 & 25 \\
\hline Nong Prue* & 25 & 5 & & & 70 \\
\hline Bang Chahlong & 20 & 70 & & & 10 \\
\hline \multicolumn{6}{|l|}{ Bang Sao Thong } \\
\hline Bang Sao Thong & 60 & 20 & 10 & 4 & 6 \\
\hline Srisajorakhe Noi & 85 & 15 & & & \\
\hline Srisajorakhe Yai & 70 & 10 & & & 20 \\
\hline
\end{tabular}

Note: * Suvarnbhumi International Airport is located in both sub-districts.

In Bang Pli, industrial areas in five out of six sub-districts are allowed. Therefore an increase in urban expansion was reported; whereas in Bang Pli Yai, which is not designated as an industrial area, the urban expansion decreases. However, the industrial categorization is not the only cause of urban 
expansion. The highest urban expansion is reported in Bang Kaew where the land use planning is for both residential and industrial areas. The area in Nong Prue is mostly industrial (70\% of the area) while the shift to intensive development is only $15 \%$ (see Table 3).

In Bang Sao Thong, natural lands dominate according to the land use policy. More than $60 \%$ are defined as green and agricultural lands, especially in Srisajorakhe Noi where the highest green area is enforced by $80 \%$ of the total area. Land use planning is effective to control urban expansion in the area designated as the green area, such as Bang Sao Thong where the shift to urban area is negligible; as illustrated in Table 3.

In comparison, the difference of urban expansion under the enforcement of the Integrated Town and Country Planning in both areas is notable. Urban expansion in Bang Sao Thong is remarkably less than in Bang Pli (see Table 3) and complies with designated urban planning.

Land use change is mainly associated with the enforcement of urban laws and regulations. This study illustrates that the Integrated Town and Country Planning is very effective in controling over-development induced by the development of mega projects in the areas even though legislation came into effect very late.

\subsection{Related Factors}

The result of the study reveals that an increase in the city area (Group A) and decrease of the green area (Group B) are both statistically significant. In this part, three factors affecting urban growth are considered, namely population change, number of dwelling units and number of factories during the period 1993 to 2005 [26], which is the same period for land use comparison of before and during airport development, previously described. Population and dwelling units are fundamental in affecting factors of urban growth. Moreover, there are three industrial estates located in the study area, apart from the areas defined as an industrial location. The results show (Table 6) that an increase in number of population and dwelling units in Bang Pli is significant whereas that in Bang Sao Thong is unremarkable. The land use planning retards urban growth in Bang Sao Thong because the green area is designated at more than $60 \%$ of the total area. Decrease in both population and dwelling units in Bang Sao Thong is clearly observed in 2001, compared with the previous year. In contrast, urban expansion in Group A is significant in Bang Pli, in five out of six sub-districts (see Table 3).

Table 7 illustrates statistical correlation or relationships among three factors from 1993 to 2005. The positive relationship between number of population and number of dwelling units is remarkable, whereas the positive relationship between number of population and number of factories is insignificant. In both areas, number of population and number of dwelling units are closely related and highly statistically correlated $(P<0.01)$. However, population change in both areas is inversely related which complies with land use enforcement. The increased number of factories in Bang Pli and Bang Sao Thong shows high statistical correlation $(P<0.01)$. In Bang Sao Thong, factory number shows opposite trend with population and dwelling units which is different from Bang Pli. 
Table 6. Number of population, dwelling units and factories during 1993-2005.

\begin{tabular}{ccccccc}
\hline Years & \multicolumn{2}{c}{ Number of population } & \multicolumn{2}{c}{ Number of dwelling units } & \multicolumn{2}{c}{ Number of factories } \\
\cline { 2 - 7 } & Bang Pli & $\begin{array}{c}\text { Bang Sao } \\
\text { Thong }\end{array}$ & Bang Pli & $\begin{array}{c}\text { Bang Sao } \\
\text { Thong }\end{array}$ & Bang Pli & $\begin{array}{c}\text { Bang Sao } \\
\text { Thong }\end{array}$ \\
\hline 1993 & 122,169 & 34,639 & 44,536 & 13,109 & 100 & 33 \\
1994 & 126,301 & 36,294 & 53,960 & 16,229 & 59 & 34 \\
1995 & 129,068 & 37,096 & 58,487 & 19,878 & 99 & 53 \\
1996 & 133,377 & 39,392 & 62,649 & 22,213 & 89 & 47 \\
1997 & 133,843 & 41,172 & 66,264 & 23,097 & 63 & 27 \\
1998 & 136,926 & 43,226 & 68,050 & 23,792 & 46 & 26 \\
1999 & 139,546 & 44,615 & 68,667 & 24,270 & 86 & 29 \\
2000 & 143,645 & 45,588 & 69,480 & 24,497 & 66 & 38 \\
2001 & 140,686 & 32,228 & 69,226 & 17,016 & 69 & 32 \\
2002 & 144,664 & 33,137 & 70,421 & 17,503 & 84 & 40 \\
2003 & 148,595 & 33,734 & 72,510 & 17,962 & 79 & 62 \\
2004 & 151,715 & 35,622 & 76,257 & 18,973 & 127 & 66 \\
2005 & 157,905 & 37,309 & 80,218 & 19,589 & 104 & 63 \\
\hline
\end{tabular}

Source: Department of Provincial Administration, 2010 [26]

Table 7. Pearson correlation coefficients of population, dwelling units and factories.

\begin{tabular}{lcccccc}
\hline & \multicolumn{2}{c}{ Population } & \multicolumn{2}{c}{ Dwelling unit } & \multicolumn{2}{c}{ Factories } \\
\cline { 2 - 7 } & Bang Pli & $\begin{array}{c}\text { Bang Sao } \\
\text { Thong }\end{array}$ & $\begin{array}{c}\text { Bang } \\
\text { Pli }\end{array}$ & $\begin{array}{c}\text { Bang Sao } \\
\text { Thong }\end{array}$ & $\begin{array}{c}\text { Bang } \\
\text { Pli }\end{array}$ & $\begin{array}{c}\text { Bang Sao } \\
\text { Thong }\end{array}$ \\
\hline $\begin{array}{l}\text { Population } \\
\text { Bang Pli }\end{array}$ & 1 & & & & & \\
$\quad$ Bang Sao Thong & -0.055 & & & & & \\
\hline Dwelling unit & & & & & \\
$\quad$ Bang Pli & $0.950 * *$ & 0.096 & & & & \\
Bang Sao Thong & 0.213 & $0.880 * *$ & 0.430 & & & \\
\hline Industry established & & & & & & \\
Bang Pli & 0.305 & -0.353 & 0.134 & -0.310 & & \\
Bang Sao Thong & $0.600 *$ & -0.387 & 0.452 & -0.193 & $0.718 * *$ & \\
\hline
\end{tabular}

Note: $*$ correlation is significant at $0.05 . * *$ correlation is significant at 0.01 .

An outstanding point of the previous land cover in the study area is the integrated agricultural and industrial area. Before the land use planning was put into effect in 2002, only the industrial area was controlled making the industrial area obviously defined. Such a pattern has been the characteristic of the area for a long time and does not affect the city environment. However, in 1996, the government clarified the mega project implementation (Suvarnbhumi Airport) after 30 years of land preparation which was theinitial stage of other developments such as roads, public utilities, many types of dwelling units and especially the transportation project linking the airport with the center of Bangkok Metropolis. Moreover, new housing projects have been developed along the new transportation routes. From the correlation of the factors in Table 7, it is found that population change relates to an increase of dwelling units but not industries. At the same time, distance from the capital city is a minor factor for an increase in housing units in the study area because the development of urbanized areas just took 
place after the construction of the airport, unlike in developed countries with strict land use planning. In the study area, there are a number of weak points in enforcing the Town and Country Planning. The distribution of dwelling units can be enforced in housing estates in natural conservation areas. However, it does not cover all types of dwelling units. Therefore, dwelling units can be located in any area, even in industrial areas without spatial separation.

\section{Conclusion}

Land use change in association with urban sprawl is a crucial factor to be considered during the set up of measures to maintain environmental sustainability. It is necessary to understand the pattern of such changes to assess the extent of their influence from past to current urban development processes in order to predict consequences on the environment. In Thailand, an Asian country, urban area has rapidly expanded since the adaptation of the National Economic and Social Development Plan in 1957. Economic benefit is likely to conflict with loss of natural areas. Uncontrolled land use change, especially to urban areas, subsequently affects sustainability development.

Significant urban expansion induced by the mega project development is clearly outlined in this study. However, there are also some factors which control such over-expansion. The Integrated Town and Country Planning which designates the areas for specific purposes is effective in limiting urban expansion. The difference of urban expansion in the two main areas, as previously described, confirms the need of urban planning.

Urban growth was induced by the increase in population and dwelling areas. Many newly-established projects, especially property projects, arise in areas with current and future transportation networks established near Bangkok Metropolis, the capital of Thailand. This usually happens in the area close to the airport. The pattern of growth aligns with the results in other developing countries such as Hanoi in Vietnam where rapid growth at the peri-urban zones resulted in increased commercial development along arterial roads connecting cities and countryside [3].

Moreover, the characteristics of urban growth shift from agricultural lands to residential lands. However, this conclusion is not true for other developments; for example the land use of one particular sensitive industrial project is somewhat different because most factories are located in their own lands and there are sufficient industrial laws and regulations to control their activities. In the case of housing expansion, these reasons are not applicable. The Integrated Town and Country Planning is only one of the tools to control housing development by limiting the green area for specific purposes. However, more mechanisms have necessarily been employed.

Within agricultural lands, there are some changes depending on the particular condition in each region, for example the studies in Greece by Zomeni et al. [14] and in France by Mottet et al. [27]. In agricultural lands, improper farming management could have long-term effects on natural resources. Economic benefit is also a main factor to induce farmers to change the type of their farm. Consequently, further environmental conditions, especially ecological factors within the areas, are affected. However, green areas are still maintained as per the land use classification.

Urban planning laws and regulations have influence on land development, especially the extent of urban expansion and protection of natural areas $[5,13,16]$. In this study, although the mega project 
development is a main driving force for urban expansion by inducing various development projects in the area, over-expansion can be prevented by land use planning policy as well as laws and regulations.

\section{Acknowledgements}

This paper is based on research in the project "The development of mechanisms for strategic ecological environmental assessment; Suvarnabhumi Airport case study" which is funded by Office of the Commission for Higher Education together with Thailand Research Fund. It is also partially supported by Faculty of Science, Silpakorn University.

\section{References and Notes}

1. Ruiz, A.M.; Montes, L.M. Environmental indicators to evaluate spatial and water planning in the coast of Granada (Spain). Land Use Policy 2008, 25, 95-105.

2. Ningal, T.; Hartemink, A.E.; Bregt, A.K. Land use change and population growth in the Morobe province of Papua New Guinea between 1975 and 2000. J. Environ. Manag. 2008, 87, 117-124.

3. Thapa, R.B.; Murayama, Y. Land evaluation for peri-urban agriculture using analytical hierarchical process and geographic information system techniques: A case study of Hanoi. Land Use Policy 2008, 25, 225-239.

4. Beardsley, K.; Thorne, J.H.; Roth, N.E.; Gao, S.; McCoy, M.C. Assessing the influence of rapid urban growth and regional policies on biological resources. Landsc. Urban Plan. 2009, 93, 172-183.

5. Su, W.; Gu, C.; Yang, G.; Chen, S.; Zhen, F. Measuring the impact of urban sprawl on natural landscape pattern of the Western Taihu lake watershed, China. Landsc. Urban Plan. 2010, 95, 61-67.

6. Solon, J. Spatial context of urbanization: landscape pattern and change between 1950 and 1990 in the Warsaw metropolitan area, Poland. Landsc. Urban Plan. 2009, 93, 250-261.

7. Moorman, C.; Mason, J.; Hess, G.; Sinclair, K. Designing suburban greenways to provide habitat for forest-breeding birds. Landsc. Urban Plan. 2006, 80, 153-164.

8. Tang, B.S.; Yui, C.Y. Space and scale: A study of development intensity and housing price in Hong Kong. Landsc. Urban Plan. 2010, 96, 172-182.

9. Xiao, H.; Weng, Q. The impact of land ause and land cover changes on land surface temperature in a Karst area of China. J. Environ. Manag. 2007, 85, 245-257.

10. Martinuzzi, S.; Gould, W.A.; Ramos Gonalez, O.M. Land development, land use, and urban sprawl in Puerto Rico integration remote sensing and population census data. Landsc. Urban Plan. 2006, 79, 288-297.

11. Pauliet, S.; Ennos, R.; Goging, Y. Modeling the environmental impacts of urban land use and land cover change: A study in Merseyside, UK. Landsc. Urban Plan. 2005, 71, 295-310.

12. Blaschke, T. The role of the spatial dimension within the framework of sustainable landscapes and natural capital. Landsc. Urban Plan. 2006, 75, 198-226.

13. Schneeberger, N.; Burgi, M.; Kienast, P.D.F. Rates of landscape change at the northern fringe of the Swiss Alps: historical and recent tendencies. Landsc. Urban Plan. 2006, 80, 127-136. 
14. Zomeni, M.; Tzanopoulos, J.; Pantis, J.D. Historical analysis of landscape change using remote sensing techniques: an explanatory tool for agricultural transformation in Greek rural areas. Landsc. Urban Plan. 2008, 86, 38-46.

15. Antwi, E.K.; Krawczynski, R.; Wiegleb, G. Detecting the effect of disturbance on habitat diversity and land cover change in a post-mining area using GIS. Landsc. Urban Plan. 2008, 87, 22-32.

16. Kim, J.; Ellis, C.D. Determining the effects of local development regulations on landscape structure: Comparison of the woodlands and North Houston. Landsc. Urban Plan. 2009, 92, 293-303.

17. Hu, D.; Huang, S.1.; Feng, O.; Li, F.; Zhoa, J.J.; Zhao, Y.H.; Weang, B.N. Relationships between rapid urban development and the appropriation of ecosystems in Jiangyin City, Eastern China. Landsc. Urban Plan. 2008, 87, 180-191.

18. Wang, S.H.; Huang, S.L.; Budd, W.W. Sprawl in Taipei's peri-urban zone: Responses to spatial planning and implications for adapting global environmental change. Landsc. Urban Plan. 2009, 90, 20-32.

19. He, C.; Okada, N.; Zhang, Q.; Shi, P.; Li, J. Modeling dynamic urban expansion processes incorporating a potential model with cellular automata. Landsc. Urban Plan. 2008, 86, 79-91.

20. Lin, Y.P.; Hong, N.M.; Wu, P.J.; Wu, C.F.; Verburg, P.H. Impacts of land use change scenarios on hydrology and land use patterns in the $\mathrm{Wu}-\mathrm{Tu}$ watershed in Northern Taiwan. Landsc. Urban Plan. 2006, 80, 111-126.

21. Musacchino, L.R.; Coulson, R.N. Landscape ecological planning process for wetland, waterfowl, and farmland conservation. Landsc. Urban Plan. 2001, 56, 125-147.

22. Brunckhorst, D.; Coop, P.; Reeve, I. Eco-civic optimisation: A nested framework for planning and managing landscape. Landsc. Urban Plan. 2005, 75, 265-281.

23. Oh, K.; Jeong, Y.; Lee, D.; Lee, W.; Choi, J. Determining development density using the urban carrying capacity assessment system. Landsc. Urban Plan. 2005, 73, 1-15.

24. Bailey, N.; Lee, J.T.; Thomson, S. Maximizing the natural capital benefits of habitat creation: spatially targeting native woodland using GIS. Landsc. Urban Plan. 2005, 75, 227-243.

25. Hara, Y.; K. Takeuchi, K.; Okubo, S. Urbanization linked with past agricultural landuse patterns in the urban fringe of a deltaic Asian mega-city: A case study in Bangkok. Landsc. Urban Plan. 2005, 73, 16-28.

26. Department of Provincial Administration, Thailand. Statistical Data of Population, Dwelling Unit and Industries. Available online: http://www.dopa.go.th (accessed on 17 January 2010).

27. Mottet, A.; Ladet, S.; Coque, N.; Gibon, A. Agricultural land use change and its drivers in mountain landscapes: a case study in the Pyreness. Agric. Ecosyst. Environ. 2006, 114, 296-310.

(C) 2011 by the authors; licensee MDPI, Basel, Switzerland. This article is an open access article distributed under the terms and conditions of the Creative Commons Attribution license (http://creativecommons.org/licenses/by/3.0/). 